\title{
Economic Analysis of Solid Waste Treatment Plants Using Pyrolysis
}

\author{
Huseyin M. Cekirge ${ }^{1}$, Omar K. M. Ouda ${ }^{2}$, Ammar Elhassan $^{3}$ \\ ${ }^{1}$ Department of Mechanical Engineering, Prince Mohammad Bin Fahd University, Al Khobar, KSA \\ ${ }^{2}$ Department of Civil Engineering, Prince Mohammad Bin Fahd University, Al Khobar, KSA \\ ${ }^{3}$ Department of Information Technology, Prince Mohammad Bin Fahd University, Al Khobar, KSA \\ Email address: \\ hmcekirge@usa.net (H. M. Cekirge),oouda@pmu.edu.sa (O. K. M. Ouda), aelhassan@pmu.edu.sa (A.Elhassan)
}

\section{To cite this article:}

Huseyin M. Cekirge, Omar K. M. Ouda, Ammar Elhassan. Economic Analysis of Solid Waste Treatment Plants Using Pyrolysis. American Journal of Energy Engineering. Vol. 3, No. 2, 2015, pp. 11-15. doi: 10.11648/j.ajee.20150302.11

\begin{abstract}
Municipal Solid Waste (MSW) management is a chronic environmental and economic problem in urban areas worldwide and more specifically in developing countries. Waste-to-Energy (WTE) technologies show a great potential to convert this problem to a revenue source. Pyrolysis is a promising technology and is currently utilized in many regions of the world for MSW disposal and energy generation. The economic value of pyrolysis has been insufficiently evaluated. This paper introduces and discusses the economic value of pyrolysis as MSW management disposal method and energy source. The return period of investments is considered for various pricing policies with respect to end product of process. Hypotheses and conclusions of the model works are briefly reported.
\end{abstract}

Keywords: Waste to Energy, Pyrolysis, Municipal Solid Waste Management

\section{Introduction}

Municipal Solid Waste (MSW) refers to domestic solid waste such as food scraps, paper, cardboard, plastics, clothing, glass, metals, wood, street sweepings, landscape and tree trimmings and general wastes from parks and other recreational areas. The world urban areas generated about 1.3 billion tons of solid waste in 2012. This volume is expected to increase to 2.2 billion tons by 2025 . Waste generation rates will more than double over the next twenty years in developing countries. Globally, solid waste management costs will increase from today's annual US \$ 205.4 billion to about US $\$ 375.5$ billion in 2025 . Cost increases will be most severe in developing countries such as Pakistan $[1,2]$. In developing countries, urban MSW is usually a city's single largest budgetary item and it can be a valuable source of biomass, recycled materials, energy and revenue if properly and wisely managed. Several energy recovery or waste-to-energy (WTE) technologies such as pyrolysis, anaerobic digestion (AD), incineration and refused derived fuel (RDF) have been developed in order to generate energy and value-added products in the form of electricity, transportation fuels, heat, fertilizers and chemicals[3,4]. Studies show that WTE can contribute substantially to energy demand especially in heavily populated urban areas [5-13]. Additionally, the WTE environmental value is quite significant with several factors including, but not limited to, greenhouse gas emission reduction, energy saving, landfill area saving, and soil and groundwater protections [14-16].

Pyrolysis is a promising technology and is currently utilized in many regions of the world for MSW disposal and energy generation. The economic value of pyrolysis has been insufficiently evaluated. This paper introduces and discusses the economic value of pyrolysis as MSW management disposal method and energy source. Fast and slow pyrolyses are considered as thermal processes, essential final products are gases, liquid fuel and electricity. Models are proposed to cover and analyze all these products. In these models fast pyrolysis and its products pyrolysis oil is not considered. The paper has three sections:

1) Estimation of income from solid waste

2) Investment calculations

3) Maintenance costs

The estimations were made by considering realistic input values and the return periods for each element were calculated. The models can be used with multi product 
estimation such as electricity, gas and liquefied gas.

\section{Estimation of Income from Solid Waste}

The capacity of a plant can be determined by considering input solid waste. Typically a person produces MSW at a rate of $0.5 \mathrm{~kg}$ to $2.5 \mathrm{~kg}$ per day and the waste has carbon content at 20-35 percent[1,2].These numbers are dependent on area, culture and income levels.

The products, defined by Table 1 , are electricity, gas and liquid fuel. The reactor may produce these products in predefined percentages. Because electricity, gas and liquid fuel can be produced in different percentages, and the system can be designed for one product otherwise the percentages of the products must be defined.

The thermodynamic constants are taken from Cengel and Boles [2014]. The composition and the caloric value of MSW, MSW per capita are taken from Hoornweg and Bhada-Tata [2012]. The part of MSW for pyrolysis is about 15 to 20 percent of the MSW, which varies according to the recycling rates of the MSW; these parameters are defined by Table 2. The population, MSW per capita and the percentage of pyrolysis material dictate the production capacity of the plant.

Table 1. Definition of products from the process.

\begin{tabular}{lll}
\hline ELECTRICITY_PRODUCTION? (YES - NO) & YES & $\mathbf{1}$ \\
\hline PERCENTAGE_OF_ELECTRICITY $(0-100)$ & 100 & $\%$ \\
GAS_GAS_PRODUCTION? (YES - NO) & NO & 0 \\
PERCENTAGE_OF_GAS $(0-100)$ & 0 & $\%$ \\
LIQUID_FUEL PRODUCTION? (YES - NO) & NO & 0 \\
PERCENTAGE_OF_LIQUID_FUEL $(0-100)$ & 0 & $\%$ \\
\hline
\end{tabular}

Table 2. Definition of system parameters.

\begin{tabular}{lll}
\hline 1_KG_TRASH_CALORIC_VALUE & $\mathbf{2 , 0 0 0 . 0 0}$ & KCAL \\
\hline 1_KCAL & 0.001163 & KWH \\
1_KG_ORGANIC_TRASH_KWH_VALUE & 2.33 & KWH \\
POPULATION & 200,000 & \\
MSW_PER_CAPITA & 1.60 & KG \\
PYROLYSIS_MATERIAL_PERCENTAGE(0-25) & 20 & $\%$ \\
PLANT_MATERIAL_DAILY_FOR_PYROLYSIS & 64.00 & TON \\
\hline
\end{tabular}

If the plant produces electricity, the income and the power of the plant can be seen on Table 3 .

Table 3. Estimation of the income from electricity production and the power of the plant.

\begin{tabular}{|c|c|c|}
\hline EFFICIENCY_FOR_TRASH_PERCENT (80 - 100) & 90 & $\%$ \\
\hline KWH_PRICE_\$ & 0.08 & $\$$ \\
\hline DAILY_ENERGY_FROM_ELECTRICITY & $133,977.60$ & KWH \\
\hline INCOME_\$_PER_YEAR_FROM_ELECTRICITY & $3,912,145.92$ & $\$$ \\
\hline POWER_MW & 5.58 & MW \\
\hline
\end{tabular}

The incomes from gas and liquid fuel are presented by Tables 3 and 4 , respectively. It should be noted that the

calculations are performed per gas or liquid fuel production only.

Table 4. Estimation income from only gas production during pyrolysis.

\begin{tabular}{llc}
\hline GAS_EFFICIENCY_PERCENT (80 - 100) & 90 & \% \\
\hline PRICE_OF_GAS_PER_M3 & 0.35 \\
ENERGY_PER_M3_IN_GAS & 45.00 & \$__ \\
1_KWH & 3.60 & MEGAJOULE \\
ENERGY_PER_M3_IN_GAS & 12.50 \\
AMOUNT_GAS_PER_DAY & $9,646.39$ \\
YEARLY_INCOME_FROM_GAS & $1,243,705.87$ \\
\hline
\end{tabular}

Table 5. Estimation income from only liquid fuel production during pyrolysis.

\begin{tabular}{|c|c|c|}
\hline LIQUID_FUEL_PODUCTION_EFFICIENCY_PERCENT (80 - 100) & 90 & $\%$ \\
\hline LIQUID_FUEL_PRICE_PER_LITER & 0.70 & $\$$ \\
\hline OPERATING COST & 0.06 & $\$$ \\
\hline LIQUID_FUEL_PER_TON(100 - 300) & 100.00 & LITER \\
\hline DAILY_PRODUCTION_LIQUID_FUEL & $5,760.00$ & LITER \\
\hline YEARLY_INCOME_FROM_LIQUID_FUEL & $1,345,536.00$ & $\$$ \\
\hline
\end{tabular}

The efficiency values presented by Tables 3,4 and 5 depend on the system and the contents of the MSW system and these values vary $80-100 \%$ of the whole pyrolysis material. The prices of electricity, gas and liquid fuel are according to prevailing market values of these commodities. However, the price of electricity is affected by government 
regulations and subsidies and varies from 3 to 20 US cents. Liquid fuel is produced through Fischer-Tropsch process at a rate of 100 to 300 liters per ton [17-20].

Table 6. The incomes from the sale of recyclables, biochar, carbon credit, gate (tipping) and brown water.

\begin{tabular}{lll}
\hline RECYCLABLE_SALES_PER_TON_\$ & $\mathbf{0 . 0 0}$ & $\mathbf{\$}$ \\
\hline PERCENTAGE_OF_RECYCLABLE (0 - 20) & 0 & $\%$ \\
DAILY_AMOUNT_OF_RECYCLABLE & 0.00 & TON \\
YEARLY_RECYCLABLE_SALES_\$ & 0.00 & $\$$ \\
BIO_CHAR_\$_PER_TON & 0.00 & $\$$ \\
PERCENTAGE_OF_CHARCOAL $(0-2)$ & 0 & $\%$ \\
DAILY_AMOUNT_OF_CHARCOAL & 0.00 & TON \\
YEARLY_BIO_CHAR_SALES_\$ & 0.00 & $\$$ \\
CARBON_CREDIT_\$_PER_TON & 0.00 & $\$$ \\
PERCENTAGE_FOR_CARBON_CREDIT $(0-100)$ & 0 & $\%$ \\
DAILY_AMOUNT_OF_CARBON_CREDIT & 0 & TON \\
YEARLY_CARBON_CREDIT_\$ & 0.00 & $\$$ \\
GATE_(TIPPING)_FEE_\$_PER_TON & 0.00 & $\$$ \\
PERCENTAGE_OF_GATE (TIPPING) (90-100) & 0 & $\%$ \\
DAILY_AMOUNT_OF_GATE (TIPPING) & 0.00 & TON \\
YEARLY_GATE_(TIPPING)_FEE_\$_ & 0.00 & $\$$ \\
BROWN_WATER_\$PER_TON & 0.00 & $\$$ \\
PERCENTAGE_OF_WATER (0- 80) & 0 & $\%$ \\
DAILY_AMOUNT_OF_BROWN_WATER & 0 & TON \\
YEARLY_INCOME_BROWN_WATER_\$ & 0.00 & $\$$ \\
\hline
\end{tabular}

The incomes from of recyclables, biochar, carbon credit, gate (tipping) and brown water are presented in Table 6 . The sale values can be determined through the agreements with local municipalities. The percentage of recyclable( $0-20)$; charcoal percentage $(0-2)$, carbon credit percentage ( 0 $100)$, tipping percentage $(90-100)$ and percentage of water $(0-80)$ are all dependent on the content of the MSW.

\section{Total Income}

Total income is estimated by adding these incomes which are possible if the sale of these products are present. The income from one tone of household waste (trash) can be estimated. In this calculation, only the sale of electricity is considered; if gas and liquid fuel are also to be produced and their production rates are as per Table 1 .

Table 7. Total income.

\begin{tabular}{lll}
\hline TOTAL_INCOME_YEARLY_\$ & $\mathbf{3 , 9 1 2 , 1 4 5 . 9 2}$ & $\mathbf{\$}$ \\
\hline INCOME_OF_PROCESSED_ONE_TON_TRASH_ & 33.49 & $\$$ \\
\hline
\end{tabular}

\section{Investment Calculations}

The list of equipment is determined by considering the amount of the trash and the capacity necessary equipment, see Table 8 . The system uses slow pyrolysis [22] where the obtained gas product runs electric generators; Table 8 is set for only electricity production. Equipment for fuel liquefiers which uses Fischer-Tropsch process [17, 19] and gas filters are not considered. The dryers are required to eliminate moisture in MSW [23], and finally the moisture is used for water production. The exhaust gases are used in dryers to increase the efficiency of the system. The other components are MSW sorting unit, waste handling unit, de-sulfurization unit, gas filters and granulation system. The other components of the capital investments are civil works, engineering design, installation and commissioning. This needs rewriting, very confusing.

Table 8. List of the major items of the plant.

\begin{tabular}{|c|c|c|c|}
\hline \multicolumn{4}{|l|}{ CAPITAL INVESTMENT } \\
\hline ITEMS & Pes. & Unit Price USD & Total Price USD \\
\hline SYSTEM EFFICIENCY & 0.9 & & \\
\hline DAILY CAPACITY OF PYROLYSIS REACTOR, TON & 24 & & \\
\hline PYROLYSIS SYSTEM & 2 & $2,000,000.00$ & $4,000,000.00$ \\
\hline DAILY CAPACITY OF DRYING UNIT, TON & 70 & & \\
\hline DRYING SYSTEM & 2 & $250,000.00$ & $500,000.00$ \\
\hline DAILY CAPACITY OF CONDENSER, TON & 70 & & \\
\hline CONDENSER & 2 & $300,000.00$ & $600,000.00$ \\
\hline DAILY CAPACITY OF MSW PRESORTING, TON & 100 & & \\
\hline MSW PRESORTING & 2 & $400,000.00$ & $800,000.00$ \\
\hline DAILY CAPACITY OF WASTE HANDLING, TON & 200 & & \\
\hline WASTE HANDLING & 1 & $400,000.00$ & $400,000.00$ \\
\hline DAILY CAPACITY OF DE-SULFURIZATION UNIT, TON & 200 & & \\
\hline DE-SULFURIZATION & 1 & $350,000.00$ & $350,000.00$ \\
\hline GAS GENSET & 2 & $1,000,000.00$ & $2,000,000.00$ \\
\hline DAILY CAPACITY OF GAS FILTER UNIT, TON & 24 & & \\
\hline GAS_FILTER & 0 & $350,000.00$ & 0.00 \\
\hline DAILY CAPACITY OF LIQUIFIER UNIT, TON & 24 & & \\
\hline LIQUIFIER & 0 & $3,000,000.00$ & 0.00 \\
\hline DAILY CAPACITY OF GRANULATION UNIT, TON & 24 & & \\
\hline GRANULATION SYSTEM & 1 & $250,000.00$ & $250,000.00$ \\
\hline CIVIL WORKS & 1 & $1,000,000.00$ & $1,000,000.00$ \\
\hline PROJECT AND ENGINEERING & 1 & $500,000.00$ & $500,000.00$ \\
\hline INSTALLATION AND COMISSIONING & 1 & $1,000,000.00$ & $1,000,000.00$ \\
\hline TOTAL & & & $11,400,000.00$ \\
\hline
\end{tabular}




\section{Operating Expense}

Operating costs can be seen in Table 9, where the yearly profit and payback periods are also presented. The costs of the operation are payments of electricity, miscellaneous maintenance, water treatment, salaries, lubrication, and cost on unseen expenses.

Table 9. Operating expenses.

\begin{tabular}{llll}
\hline OPERATING EXPENSES & & & Daily Cost \\
\hline & Unit Cost USD & Annual Cost \\
\hline ELECTRICITY COST_@_365_DAYS & 0.03 & $3,000.00$ & $32,850.00$ \\
GENSET MAINTENANCE & 2 & $18,000.00$ & $36,000.00$ \\
GAS_FILTER_MAINTENANCE & 0 & $20,000.00$ & 0.00 \\
LIQUIFIER_MAINTENANCE & 0 & $20,000.00$ & 0.00 \\
DRYER MAINTENANCE & & & $60,000.00$ \\
CONDENSER MAINTENANCE & & & $30,000.00$ \\
WATER TREATMENT & & & $30,000.00$ \\
PYROLYSIS UNIT MAINTENANCE & & & $157,500.00$ \\
SALARIES & & & $200,000.00$ \\
OTHERS & & & $50,000.00$ \\
MSW PRESORTING MAINTENANCE & 2 & $22,000.00$ \\
HANDLING MAINTENANCE & & & $1,800.00$ \\
GAS GENSET LUBRICATION COST & & $24,000.00$ & $48,000.00$ \\
TOTAL & & & $668,150.00$ \\
GROSS PROFIT & & $2,299,784.72$ & USD/YEAR \\
PAYBACK PERIOD & & 4.96 \\
\\
\hline
\end{tabular}

The water may have some odors and these odors may be avoided by odor control technologies which are widely available on the market. Since only electricity is produced in this scenario, the cost of maintenance of gas filters and liquefiers is not withstanding.

\section{Various Scenarios and Return Period}

The important variables profit and return period for investment are the sale price of electricity and population; the various cases are presented by Table 10 and can be extended further. In these scenarios, the income from recycling, charcoal, carbon credit, tipping and produced water are not considered. If these incomes are to be taken into consideration, the profit and return period of the investment will be shortened considerably.

Table 10. Various scenarios.

\begin{tabular}{llll}
\hline POPULATION & PRICE OF ELECTRICITY, \$/kWh & PROFIT \$ & RETURN_PERIOD, YEAR \\
\hline 200,000 & 0.08 & $3,189,245.92$ & 3.57 \\
300,000 & 0.08 & $5,074,118.88$ & 2.95 \\
200,000 & 0.10 & $4,145,382.40$ & 2.75 \\
300,000 & 0.10 & $6,511,973.60$ & 2.30 \\
\hline
\end{tabular}

\section{Conclusion}

MSW is a chronic problem in urban areas. WTE technologies such as pyrolysis can be utilized to convert this problem to a revenue source if properly managed and implemented. This paper presented an economic analysis of the Pyrolysis technology as an MSW management option. The analysis showed that the determining factor in WTE investment is the selling price of electricity. However, more comprehensive scenarios can be developed where electricity, gas and liquid fuel production are considered with their selected production percentages.

\section{References}

[1] D. Hoornweg and L. Thomas, 1999. What a Waste: Solid Waste Management in Asia. East Asia and Pacific Region.
Urban and Local Government Working Paper. World Bank. 1818 H Street, NW, Washington, DC 20433 USA.

[2] Daniel Hoornweg and Perinaz Bhada-Tata, What A Waste a Global Review of Solid Waste Management, Urban Development \& Local Government Unit, World Bank, $1818 \mathrm{H}$ Street, NW, Washington, DC 20433 USA, www.worldbank.org/urban, No. 15, March 2012.

[3] P. Costi, R. Minciardi, M. Robba, M. Rovatti, M. and R. Sacile, (2004). An environmentally sustainable decision model for urban solid waste management, waste management, 24(3), 277-295.

[4] S. J. Burnley, (2007) "A review of municipal solid waste composition in the United kingdom" Vol. 27, No. 10. pp. 1274-1285.

[5] ASME, American Society of Mechanical Engineers (2008), Waste-to-Energy: A renewable Energy Source from Municipal Solid Wastes, White paper submitted to the Congress, 2008. 
[6] UNEP, United Nations Environmental Program (1996), International Source Book on Environmentally Sound Technologies for Municipal Solid Waste Management, Osaka/Shiga.

[7] O. K. M. Ouda, S. A. Raza, R. Al-Waked, J. F. Al-Asad and Nizami, A-S.,(2015).Waste-to-Energy Potential in the Western Province of Saudi Arabia, Journal of King Saud University Engineering Sciences, doi:

http://dx.doi.org/10.1016/j.jksues.2015.02.002

[8] O. K. M. Ouda, H. M. Cekirge and R. Syed, (2013), An assessment of the potential contribution from waste-to-energy facilities to electricity demand in Saudi Arabia, Energy Conversion and Management 75, pp. 402-406.

[9] O. K. M. Ouda and H. M. Cekirge, (2014), Roadmap for Development of Waste-to Energy Facility in Saudi Arabia, American Journal of Environmental Engineering 3(6), pp. 267-272.

[10] B. S. Tawabini, O. K. M. Ouda and S. A. Raza, (2014). Investigating of Waste to Energy Potential as a Renewable Energy Resource in Al-Hasa Region, Saudi Arabia, 5th International Symposium on Energy from Biomass and Waste( VENICE 2014). 17-20 November 2014, Venice, Italy.

[11] O. Aga, O. K. M. Ouda and S. A. Raza, (2014), Investigating Waste to Energy Potential in the Eastern Region, Saudi Arabia, Renewable Energy for Developing Countries (REDEC 2014), November 26-27, 2014, Beirut, Lebanon,

[12] R. Al-Waked, O. K. M. Ouda and S. A. Raza, (2014), Potential Value of Waste to Energy Facility in Riyadh City - Saudi Arabia, the Eighth Jordanian International Mechanical Engineering Conference (JIMEC 8), September 22-23, 2014, Amman, Jordan.

[13] O. K. M. Ouda and S. A. Raza, (2014). Waste-to-Energy: Solution for Municipal Solid Waste Challenges- Global Annual Investment, 2014 IEEE International Symposium on Technology Management and Emerging Technology (ISTMET), May 27-29, 2014, Bandung, West Java, Indonesia.

[14] M. M. Gilbert and P. E. Wendell, Introduction to Environmental Engineering and Science, Chapter 9: Solid Waste Management and Resource Recovery, Third Edition, Pearson Education Inc., 2008, ISBN-13:978-0-13-233934-6.
[15] O. K. M. Ouda and H. M. Cekirge, (2014). Potential Environmental Values of Waste-to-Energy Facilities in Saudi Arabia, the Arabian Journal for Science and Engineering (AJSE) 39 (11), pp 7525-7533.

[16] O. K. M. Ouda, (2013), Assessment of the Environmental Values of Waste-to-Energy in the Gaza Strip, Current World Environment 8(3), pp. 355-364.

[17] L. Mahjoob and H. Nezihi Ogul, (private communication) American Combustion Technologies, Inc., Los Angeles, California, 2014.

[18] Yunus A. Cengel and Michael A. Boles Thermodynamics: An Engineering Approach, 8th Edition, New York, McGraw-Hill, 2014.

[19] Jin $\mathrm{Hu}$ Fei $\mathrm{Yu}$ and Yongwu Lu, Application of FischerTropsch Synthesis in Biomass to Liquid Conversion, Catalysts, 2, 303-326, 2012

[20] Gary C. Young, (2010), Municipal Solid Waste to Energy Conversion Processes: Economic, Technical and Renewable Comparisons, John Wiley \& Sons, Hoboken, New Jersey, 2010.

[21] Maura Farver and Christopher Frantz (2013), Garbage to Gasoline: Converting Municipal Solid Waste to Liquid Fuels Technologies, Commercialization, and Policy Duke University Nicholas School of the Environment April, 2013.

[22] Anh N. Phan, Changkook Ryu, Vida N. Sharifi and Jim Swithenbank (2008), Characterisation of Slow Pyrolysis Products from Segregated Wastes for Energy Production, Journal of Analytical and Applied Pyrolysis, Pages 65-71, Volume 81, Issue 1, January 2008.

[23] Chen Shu, Ma Xiao-Qian and Liang Zeng-Ying, (2014), Moisture Transfer Models and Drying Characteristics of MSW Containing High Moisture, TELKOMNIKA Indonesian Journal of Electrical Engineering, Vol.12, No.3, 1741 - 1750, March 2014. 